Article

\title{
Accomplice to Mass Atrocities: The International Community and Indonesia's Invasion of East Timor
}

\author{
Clinton Fernandes \\ School of Humanities and Social Sciences, UNSW Canberra, Canberra, ACT 2600, Australia; \\ E-Mail: c.fernandes@adfa.edu.au
}

Submitted: 2 April 2015 | In Revised Form: 5 June 2015 | Accepted: 24 June 2015 |

Published: 26 November 2015

\begin{abstract}
This paper examines early warning of, and political responses to, mass atrocities in East Timor in the late 1970s. Using newly-declassified intelligence and diplomatic records, it describes Indonesia's invasion of East Timor in 1975 and its three year military campaign to crush the East Timorese resistance. It shows that the campaign resulted in mass deaths due to famine and disease, and considers the United Nations' response to the unfolding crisis. It evaluates the level of international awareness of the humanitarian crisis in East Timor by inspecting contemporaneous eyewitness reports by foreign diplomats from states with a keen interest in Indonesia: Australia, the United States, New Zealand and Canada. In contrast to a popular, highly lauded view, the paper shows that these states did not "look away"; rather, they had early warning and ongoing knowledge of the catastrophe but provided military and diplomatic assistance to Indonesia. The paper contrasts a counter-productive effort by civil society activists with a very effective one, and thus demonstrates the role that robust scholarship can play in terminating atrocities.
\end{abstract}

\section{Keywords}

atrocities; Australia; crimes against humanity; East Timor; famine; genocide; Indonesia; responsibility to protect; R2P; United Nations; war crimes

\section{Issue}

This article is part of the special issue "Mass Atrocity Prevention", edited by Professor Karen E. Smith (London School of Economics and Political Science, UK).

(C) 2015 by the author; licensee Cogitatio (Lisbon, Portugal). This article is licensed under a Creative Commons Attribution 4.0 International License (CC BY).

\section{Introduction}

This paper examines early warning of, and political responses to, mass atrocities in East Timor in the late 1970s. It begins with an historical synopsis that examines the Indonesian invasion of East Timor. It shows that Indonesia's three year military campaign to crush the East Timorese resistance resulted in mass deaths due to famine and disease. It then considers the United Nations' response to the unfolding crisis. It goes on to evaluate the level of international awareness of the humanitarian crisis in East Timor by inspecting contemporaneous eyewitness reports by foreign diplomats. In doing so, it shows that there was early warning and ongoing knowledge of the mass deaths in East
Timor; that states chose not to act to terminate the deaths; that they instead provided military and diplomatic assistance to Indonesia. The paper examines two different efforts by civil society activists to bring an end to the mass deaths.

\section{Pre-Invasion East Timor}

The Democratic Republic of East Timor consists of the eastern half of the island of Timor, as well as the enclave of Oecussi (located in West Timor) and two smaller islands, Atauro and Jaco. It has an area of approximately 15,000 square kilometres, which is slightly larger than Northern Ireland. The western half of the island is part of the Indonesian province of Nusa 
Tenggara Timur (the East Lesser Sundas).

Claimed by Portugal as a colonial possession in the 17th century, East Timor remained under Portuguese rule until the 20th century. For much of the 20th century Portugal itself was under the rule of western Europe's most enduring authoritarian system-the fascist Estado Novo, which opposed decolonisation for any of its colonies, including East Timor. On 25 April 1974, a group of Portuguese military officers known as the Armed Forces Movement overthrew the regime, disbanded the paramilitary forces, eliminated censorship and abolished the secret police. The new government formally accepted the terms of the 1960 UN Resolution on Decolonisation. East Timor became a nonautonomous territory under Portuguese administration and placed on the UN's decolonisation agenda.

Indonesia had not shown much interest in annexing East Timor during its own independence struggle in the 1940s. Nor did it show much interest during its liberal parliamentary period in the 1950s. Its Foreign Affairs Minister explicitly denied any claim to East Timor in his submissions to the First Committee of the United Nations General Assembly in 1961. However, once Portugal committed East Timor to a decolonisation process, leading Indonesian officials took the view that decolonisation should result in East Timor being annexed to Indonesia. Australia's Prime Minister advised Indonesia's President Suharto that he was "in favour of incorporation but obeisance has to be made to self determination" ${ }^{1}$. An Indonesian official later remarked that "until $\mathrm{Mr}$ Whitlam's visit to Jakarta they had been undecided about Timor. However the Prime Minister's support for the idea of incorporation into Indonesia had helped them to crystallise their own thinking and they were now firmly convinced of the wisdom of this course"2.

\section{The Indonesian Invasion of East Timor}

Inside East Timor, the two most popular political organisations were the Timorese Democratic Union (UDTUnião Democratica Timorense) and the Timorese Social Democratic Association (ASDT-Associacao Social Democratica Timorense), which changed its name to FRETILIN - the Revolutionary Front for an Independent East Timor (Frente Revolucionária do Timor-Leste Independente) in September 1974. FRETILIN and UDT agreed that East Timor should become independent, and that they would form a transitional government. They formed a political coalition in early 1975 to that effect. However, their mutual suspicion proved to be

${ }^{1}$ NAA: A11443 [1]: South-East Asia Branch, Department of Foreign Affairs and Trade (DFAT), loose papers on Portuguese Timor: July-September 1974.

2 NAA: A10005, 202/1/3, iii: DFAT Correspondence files, Portuguese Timor: negotiations and constitutional developments. too strong, and their political inexperience was exploited by Indonesia, which sought to undermine potential East Timorese unity by playing off one side against the other.

The FRETILIN-UDT coalition collapsed after four months. Indonesian intelligence advised UDT leaders that FRETILIN was planning a coup, and that Indonesia would respect East Timor's right of self-determination if UDT moved against FRETILIN. Accordingly, key UDT members led a preemptive coup against FRETILIN in the early hours of 11 August 1975. FRETILIN fought back on 20 August, defeating most of the UDT forces by 30 August. Between 1,500 and 3,000 people are estimated to have been killed during the internal armed conflict. The Portuguese governor and his administration left the mainland for the off-shore island of Atauro, and later proceeded to Portugal. The defeated forces of UDT, now located in West Timor, signed a petition calling for the integration of East Timor into Indonesia.

Indonesia accelerated its campaign of destabilisation and terror, and ultimately launched a full-scale military invasion on 7 December 1975 in order to defeat FRETILIN in battle, eliminate its leaders and suppress political organizations associated with it. Within two months, all major population centres were in Indonesian hands. By June 1976, there were approximately 32,000 combat troops in 28 battalions, supported by some 3,000 Timorese partisans and civil defence personnel ${ }^{3}$. Indonesia intended to integrate East Timor as its 27th province on 17 August 1976, its own independence day, but the Australian government, which wanted to recognise the takeover, said privately that 17 August "involved them in particular embarrassment as it is the day on which [Australia's] Parliament is to reassemble" ${ }^{4}$. Accordingly, Indonesia brought the date forward by one month, and announced the integration on 17 July 1976, during the Australian Parliamentary recess.

FRETILIN's leaders reorganized the party's national civilian and military structures in order to undertake a protracted guerrilla war. At a conference in Soibada (15 May-2 June 1976), they divided the areas outside direct Indonesian military control, known as liberated zones, into six sectors, and placed each one under military and political command. The reorganisation paid dividends as many local villagers joined the armed resistance, which took advantage of Indonesian security lapses to harass outposts and ambush supply convoys. East Timor's arterial roads were severely degraded by the heavy Indonesian military traffic and by monsoonal rains that caused major landslides. Indonesia's military logisticians were unable to cope. Combat units were

\footnotetext{
3 NAA: A13685, 1/1978: The Indonesian integration of East Timor.

${ }^{4}$ British Archives file FCO 24/2208: Political Relations between Australia and Indonesia.
} 
unable to receive timely resupplies, and Indonesia's 15 infantry and marine battalions could do little more than conduct small-scale local patrols 5 .

By December 1976, FRETILIN had managed to hold the Indonesian forces to a military stalemate. It was able to organize a functioning society in the mountains. It could provide enough food crops and basic health care to the many tens of thousands of civilians who had accompanied them there. The Indonesian general elections in May 1977 necessitated the redeployment of 14,000 combat troops from East Timor to other parts of Indonesia for pre-election security. ${ }^{6}$ By preventing Indonesia's military commanders from regaining the initiative, the elections gave FRETILIN the opportunity to recruit, retrain and reorganize.

\section{Airpower after May 1977}

Indonesia resumed military operations after the May 1977 elections. Its strategy was based on the assessment that it had to eliminate FRETILIN by the end of January 1978 because heavy rains would force operations to cease then-just as they had at the end of January 1977. It wanted to deny FRETILIN another opportunity to regroup, recruit and retrain. Starting in August 1977, it deployed OV-10F Bronco aircraft that it had acquired from the USA. The significance of the Bronco was that it could be operated from the most rudimentary airfields, and its slow flying speed meant that it could identify and attack villages more effectively. It had been designed specifically for such operations.

The air power offensives targeted agricultural areas and other food sources such as livestock in the liberated zones, where the population lived alongside FRETILIN, and the support bases, which surrounded the liberated zones. The Indonesian Air Force used napalm, which it had acquired from the USSR in 1962 (CAVR, 2006, 7.5). According to survivors who testified before East Timor's Commission for Reception, Truth and Reconciliation:

The army burned the tall grass. The fire would spread quickly, and the whole area would be ablaze as if it had been doused in gasoline. Those of us who were surrounded didn't have time to escape because the flames were so big. Their strategy trapped many people.....After we got out, I could still see the old people who had been left behind by their families. They were in a sitting position. The men put on new clothes, hung belak [crescentshaped metal chest-ornament worn around the neck] on their necks and wore caibauk [crescent-

\footnotetext{
${ }^{5}$ NAA: A13685, 1/1978: The Indonesian integration of East Timor.

${ }^{6}$ NAA: A13685, 1/1978: The Indonesian integration of East Timor.
}

shape crown]. The women had put on gold earrings and gold necklaces, prepared their konde [traditional way of styling hair] and wore black veils as if they were going to mass. We just looked at them but couldn't do anything. The enemy was still after us (CAVR, 2006, 7.3).

\section{Famine, Disease and Mass Deaths}

Illness and food shortages forced civilians to leave the hills and make their way to Indonesian forces in order to surrender. The surrendering population was first detained in transit camps and later dispatched to resettlement camps. Transit camps were located in close proximity to the local military bases. Their function was to enable the Indonesian military to identify members of the resistance and to gain intelligence on the rest of the resistance in the mountains. East Timorese collaborators helped the Indonesian military to identify members of the resistance in the transit camps. Sometimes these collaborators identified people who were not connected to the resistance but against whom they had held grudges prior to the invasion.

Torture and rape were common during the interrogation process (CAVR, 2006, 7.3, 7.7, 7.8; Fernandes, 2011, pp. 48-49). People identified as belonging to Fretilin or its armed wing were either executed immediately or interrogated at greater length and then executed. Female relatives of Fretilin leaders were often made the sexual slaves of Indonesian military officers. At the conclusion of their posting to East Timor, officers frequently transferred their "ownership rights" over these women to other officers. Women who had connections to the resistance or who were believed to know the location of members of the resistance were forced to help the Indonesian military in its search and destroy missions. They were often subjected to torture and rape during these missions.

The transit camps were not equipped to care for the welfare of the surrendering population. Often they were little more than huts made from palm thatch with no toilets. In many cases, the only shelter in the camps was under trees. No medical care was available. Since the detainees' food sources had been destroyed and they had walked for days in order to surrender, they were already in a weakened state when they arrived at the transit camps. Diseases such as cholera, diarrhoea and tuberculosis ensured that most people who were sick died. Detainees were forbidden to grow or search for food themselves but were given a small amount of food on arrival. This food was often distributed after extorting family heirlooms, jewelry, traditional beads or sexual favours. In some cases, the detainees went into protein shock after eating the food, resulting in "chills, fever, bronchial spasms, acute emphysema, vomiting and diarrhoea." (CAVR, 2006, 7.3).

After a period of three months (the exact duration 
in each camp depended on the prevailing policy there), the detainees were dispatched to resettlement camps. Sometimes they were not sent anywhere; the same transit camps were re-designated as resettlement camps. According to a secret submission to the Australian cabinet in November 1979, "about 200,000 people were in these centres in early September $1979^{\prime \prime}$. Other estimates of the population in these camps range from approximately 300,000 to 370,000 people by late 1979 (Taylor, 1991, pp. 88-90). Whatever the true figure, it should be remembered that the population of East Timor at the time of the Indonesian invasion in 1975 was about 650,000 (Staveteig, 2007, p. 14). Once again, there were severe restrictions on movement as well as inadequate food, medicine, sanitation and shelter. The result was a famine in which many tens of thousands of East Timorese died.

A demographical analysis in 2006 concluded that "Even under the most conservative assumptions, the total number of excess deaths in East Timor during the entire period of Indonesian occupation likely ranges from 150,000 to 220,000" (Staveteig, 2006). According to a revised version of this analysis, "it is likely that 204,000 is a conservative upper-bound estimate on excess mortality. The 'true' number of East Timorese who died because of the Indonesian occupation may never be known" (Staveteig, 2007). The overwhelming majority of the deaths occurred during the famine, whose most deadly phase occurred during a 19-month period in 1978 and 1979 (CAVR, 2006, p. 505).

\section{Responses by the United Nations}

Immediately after the invasion, the United Nations General Assembly strongly deplored Indonesia's military intervention in Resolution 3485 (XXX) of 12 December 1975, and stated that East Timor had the right to self-determination. The UN Security Council also confirmed East Timor's right to self-determination in Resolutions 384 (1975) of 22 December 1975 and 389 of 22 April 1976. Neither the General Assembly nor the Security Council, however, used the words "invasion", "aggression" or "condemn" in connection with Indonesia's actions. Nor was Indonesia's use of force characterised as unlawful. There were no sanctions on Indonesia. Both organs used the hortatory phrase "calls upon" rather than the more robust "demands" or "decides" in asking "the Government of Indonesia to withdraw without delay" its armed forces from the territory. There were eight General Assembly resolutions concerning East Timor from 1975 to 1982. These were adopted with a declining majority of votes.

Despite the international publicity over the famine, the 1979 Resolution contained no specific criticism of

7 NAA: A1838 3038-10-15 Part 11: Portuguese TimorAustralian Aid.
Indonesia; instead it called upon "all parties concerned" to facilitate the entry of international relief aid "in order to alleviate the suffering of the people of East Timor". Without even mentioning which country was responsible, it expressed its "deepest concern at the suffering of the people of East Timor". Indeed, the 1979 Resolution dropped all references to Article 2, paragraph 4 (requiring states to refrain from the "threat or use of force against the territorial integrity or national independence of any State") and Article 11, paragraph 3 (referring to "situations which are likely to endanger international peace and security") of the UN Charter, which had appeared in previous resolutions. The 1979 Resolution did not reaffirm previous resolutions in the preamble or in the operative part. It made no reference to East Timor's territorial integrity.

FRETILIN's representative at the UN, Jose RamosHorta, had deliberately weakened the language of the 1979 General Assembly Resolution (Resolution 34/40 of 21 November 1979) so as to arrest the declining percentage of Yes votes. The tactic was temporarily successful, as Table 1 shows.

Table 1. General Assembly votes, 1975-1982.

\begin{tabular}{lllrrr}
\hline Year & Yes & No & Abstain & $\begin{array}{r}\text { Not } \\
\text { Present }\end{array}$ & $\begin{array}{r}\text { Percentage } \\
\text { Voting Yes }\end{array}$ \\
\hline 1975 & 72 & 10 & 43 & 19 & $50 \%$ \\
1976 & 68 & 20 & 49 & 9 & $47 \%$ \\
1977 & 67 & 26 & 47 & 9 & $45 \%$ \\
1978 & 59 & 31 & 44 & 16 & $39 \%$ \\
1979 & 62 & 31 & 45 & 14 & $41 \%$ \\
1980 & 58 & 35 & 46 & 15 & $38 \%$ \\
1981 & 54 & 42 & 46 & 15 & $34 \%$ \\
1982 & 50 & 46 & 50 & 11 & $32 \%$ \\
\hline
\end{tabular}

The United States, Britain and France did not support any General Assembly resolutions from 1975 to 1982. As Permanent Members of the Security Council, they had the ability to make a difference but did not do so. The US's position was subsequently explained by its Ambassador to the UN, Daniel Patrick Moynihan, in his memoirs:

The United States wished things to turn out as they did, and worked to bring this about. The Department of State desired that the United Nations prove utterly ineffective in whatever measures it undertook. This task was given to me, and I carried it forward with no inconsiderable success (Moynihan, 1978, p. 279).

Only about one-third of the UN General Assembly, largely Third World states, kept the question of East Timor alive in the General Assembly from 1976 until 1982 , when the matter was delegated to the UN Secre- 
tary-General. Only four Western states (Cyprus, Greece, Iceland and Portugal) supported East Timor in this period.

When it occupied East Timor, the Indonesian government would not be opposed by the Non-Aligned Movement, of which it was a founding member. Nor would it be opposed by the Organisation of Islamic Conference, since it had the largest Muslim population in the world. It was also the largest state in the Association of South-East Asian Nations (ASEAN), whose members' policy of non-interference in one another's internal affairs meant that Indonesia was free from any criticism of its conduct in East Timor.

\section{Not Looking Away}

Even today, a popular but erroneous belief is that the United States looked away when Indonesia was killing East Timorese by the thousands. According to a Pulitzer Prize-winning book by a prominent scholar/diplomat, "When its ally, the oil-producing, anti-Communist Indonesia, invaded East Timor, killing between 100,000 and 200,000 civilians, the United States looked away" (Power, 2002, pp. 146-147). In fact, the United States did not look away but provided military, financial and diplomatic support to Indonesia during the early years of the invasion and for much of the occupation. George Aldrich, Deputy Legal Adviser in the State Department, admitted that the Indonesian forces that invaded East Timor "were armed roughly 90 per cent with our equipment" (US Congress, 1977, pp. 59-64). As Indonesia's napalm-enabled airpower offensives began in 1977 , the US military aid proposal totaled $\$ 51.9$ mil$\operatorname{lion}^{8}$. Later that year, a western diplomat reported that Indonesian forces were "running out of military inventory. The operations on Timor have pushed them to the wall" (McArthur, 1977). The Carter administration helped them replenish their arsenal by authorizing weapons sales of $\$ 112$ million for fiscal year 1978 (Nevins, 2005, p. 53). Vice-President Walter Mondale then flew to Jakarta and announced the sale of A-4 Skyhawk ground-attack aircraft to the Indonesian Air Force (Chomsky \& Herman, 1979, pp. 191-192). According to declassified Australian intelligence reports, the Suharto regime received "the greater part of her military aid from the US, and the remainder from Australia" ${ }^{9}$. Indonesia acquired foreign equipment as Table 2 shows.

The US provided Indonesia with military aid in the form of direct grants, credit sales and transfer from excess stocks. From 1967-1975, US military aid was US\$104 million. In addition, it sold Indonesia other equipment commercially, outside the aid program. The military assistance was unaffected by Indonesia's invasion of East Timor. Australia provided military

8 NAA: A13685 12/1976: Military Study-Indonesia, Part 1.

${ }^{9}$ NAA: A13685, 12/1976: Military Study-Indonesia, Part 1. aid-mainly in the form of equipment-in a series of three-year programs: A\$26 million from July 1972 to June 1975 and $A \$ 31$ million from July 1975 to June $1978^{10}$.

Table 2. Foreign military transfers.

\begin{tabular}{|c|c|}
\hline Armaments & Country of origin \\
\hline $\begin{array}{l}\text { V-150 armoured cars, C-130 } \\
\text { (Hercules) transport aircraft, F- } \\
51 \text { (Mustang) ground-attack } \\
\text { aircraft, OV-10F (Bronco) } \\
\text { ground-attack aircraft, T-33 } \\
\text { (Shooting Star) trainer aircraft, } \\
\text { T-34C (Turbomentor) trainer } \\
\text { aircraft, Bell } 204 \text { and } 205 \\
\text { (Iroquois) helicopters, UH-34-D } \\
\text { (Choctaw) helicopters, F-5E, F- } \\
\text { 5F and A-4 (Skyhawk) aircraft }\end{array}$ & USA \\
\hline $\begin{array}{l}\text { Patrol boats, Sabre and Nomad } \\
\text { aircraft, Sioux helicopters }\end{array}$ & Australia \\
\hline $\begin{array}{l}\text { Fokker F-27 (Troopship) } \\
\text { transport aircraft, three } \\
\text { corvettes. }\end{array}$ & The Netherlands \\
\hline $\begin{array}{l}\text { At least sixteen BO-105 } \\
\text { (Bolkow) helicopters, two } \\
\text { submarines. }\end{array}$ & West Germany \\
\hline $\begin{array}{l}\text { CASA-212 light transport } \\
\text { aircraft }\end{array}$ & Spain \\
\hline $\begin{array}{l}\text { Puma helicopters, } \\
\text { Refurbishment of AMX-13 light } \\
\text { tanks }\end{array}$ & France \\
\hline $\begin{array}{l}\text { Decca air-defence radars; Hawk } \\
\text { aircraft (on order). }\end{array}$ & UK \\
\hline
\end{tabular}

\section{Warning of the Famine-The Church in East Timor}

The use of the word "genocide" to characterise the situation in East Timor appeared in a letter from a Catholic priest smuggled out by Sister Natalia Granado Moreira and Sister Maria Auxiliadora Hernandez, who had been Dominican missionaries in East Timor. The letter was translated from the Portuguese and published in Nation Review in January 1978:

The war is entering its third year and it seems it won't stop soon. The barbarities (understandable in the stone age), the cruelties, the theft, the firing squads without any justification, are now part of everyday life in Timor. The insecurity is total and the terror of being arrested is our daily bread. (I'm on the list of the persona non grata-any day they might make me disappear.) Fretilin troops who surrender are shot dead: for them there are no

10 NAA: A13685 12/1976: Military Study-Indonesia, Part 1. 
jails....Our residence, Bispo Medeiros, was destroyed by the fire of the invaders, Dare seminary destroyed, the Catholic colleges of Maliana and Soibada destroyed. Timor was not integrated. It was annexed. It was not liberated from "communism". It was given to Islamic Indonesians. Freedom in any form does not exist.... The world ignores us and it is a pity. We are on the way to a genocide (Hurst, 1978, p. 9).

\section{Knowledge of the Famine-New Zealand Diplomats}

In the same month as the priest's letter was published, the New Zealand Ambassador to Indonesia paid a visit to East Timor (Leadbeater, 2006). He said that "in the words of one Catholic priest, 'everything was taken away' by the Indonesian troops." But he made allowances for this, commenting that this was "hardly surprising, of course. Indonesian troops have behaved badly in many of the outer provinces during the last 25 years, and at the present time they are displaying a marked lack of understanding in Irian Jaya." Over the course of his visit, he wrote, "we found ourselves placing less and less reliance" on the views of the Catholic clergy. He reported that "providing emergency accommodation and food supplies for the refugees is a huge problem for the administration at the present time, and one which will continue for some while". At Suai, in the south, he reported seeing a "make-shift camp which had been hastily erected when some 8,000 had come down from the hills only a few weeks before. This was little more than palm frond bivouacs which had been built by the refugees themselves, with assistance from the local people and the local military organisations". Rather than ring alarm bells, however, he wrote that it was "the price of success: if people were not breaking away from the FRETILIN activists there would be no refugees."

Positively disposed towards his Indonesian hosts, he reported that "the island of Timor is by no means an attractive piece of real estate.... The Timorese people are poor, small, riddled with disease and almost totally illiterate, very simple and, we were told again and again, 'primitive'. They are almost completely under the influence of their 'rajas'. Considered as human stock they are not at all impressive-and this is something that one has to think about when judging their capacity to take part in an act of self-determination or even to perform as responsible citizens of an independent country."

"We spoke no Portuguese or Tetum," he reported, "while few of the 'locals' spoke Bahasa Indonesia, so that quite often we had to get interpretation from Tetum into Portuguese into Bahasa into English." He reported that the people he spoke with were "mostly administration and administration-connected people" because "to achieve much more would have required fluency in Portuguese and Tetum and a deliberate effort to cultivate people who might regard themselves as in some degree disaffected". He said that "the FRETILIN propaganda machine has several times accused the Indonesian Government of mounting a new and massive invasion of East Timor", and admitted that "in private senior [Indonesian military] officers have acknowledged that a special effort was being made" to subdue the resistance. However, he had been assured by them that "anyone quitting FRETILIN was being received 'as a brother'...in fact only one FRETILIN activist had been captured in the strict sense of the word, a squad leader who was taken near Bobonaro, and no-one seemed to be quite sure what had happened to him"11.

\section{Knowledge of the Famine-Australian Diplomats}

Under Australian law, the Archives Act provides for the declassification of most government documents after 20 years. But the Australian government has refused to declassify its nearly 40-year old Foreign Affairs records that would reveal in full its knowledge of the famine. It claims that their release would compromise Australia's security, defence or international relations. Legal challenges and public pressure have ensured the release of many documents, however, and what they reveal is that Australian diplomats and other government officials were aware that a major humanitarian catastrophe was occurring in East Timor.

Even before the invasion, the documents show that Australian officials concluded that the "Indonesian invasion of Portuguese Timor would be contrary to Article 2(3) and (4) of the Charter which provides that international disputes shall be settled by peaceful means and obliges members to refrain from the threat or use of force, against the territorial integrity or political independence of another State"12. However, although officials believed "Indonesian action would fall into the category of outright aggression"13, influential Australian policymakers felt their aim should be to "do our best to contain the damage to the Australian/Indonesia relationship and act to limit a recrudescence of latent hostility to Indonesia in Australia"14. Australian principles, according to this view, "should be tempered by the proximity of Indonesia and its importance to us and by the relative unimportance of Portuguese Timor" ${ }^{15}$.

Australian officials were given timely and accurate

11 NAA: A1838, 3038-7-1 Part 18: Portuguese Timor: External Relations.

12 NAA: A1838 935-17-3 Part 21, iii: Portuguese Timor: UN Fourth Committee.

13 NAA: A1838 935-17-3 Part 21, iii: Portuguese Timor: UN Fourth Committee.

14 NAA: A10463 801-13-11-10 Part 1: Australian Embassy Jakarta correspondence files.

15 NAA: A10463 801-13-11-10 Part 1: Australian Embassy Jakarta correspondence files. 
advice about the catastrophic famine from highly credible sources. For example, on 24th May 1978, Australian Ambassador Tom Critchley and First Secretary David Irvine called on Indonesian Brigadier-General Adenan, Director-General for Foreign Relations and Security in Indonesia's Department of Foreign Affairs. Adenan advised them that supporters of FRETILIN were "suffering lack of both ammunition and food." Those who had surrendered recently "were in poor physical condition" and "some could not even stand"16. Here was an opportunity to offer humanitarian aid directly to the Indonesian government or to pressure it internationally to allow humanitarian aid in. But such aid would not be allowed to enter for another 17 months, and the death toll mounted.

A month later (30th June 1978), Ambassador Critchley and Acting Defence Attaché Captain R.J. Whitten called on General Mohammad Yusuf, Minister for Defence and Commander of the Indonesian Armed Forces. General Yusuf said that he had "just returned from East Timor" and that "one of the biggest problems was the 270,000 women and children to care for." The Embassy went on to note that "apparently the majority are women and children who have become separated from their menfolk." The Embassy commented that the figure:

seems unduly high to us considering that the total population of the province is somewhere between 500,000 and 600,000 . But it was repeated....General Yusuf has a reputation as a dull and taciturn officer but on this occasion he was very forthcoming and gave the impression that he was well briefed and in command of his subject-East Timor. Although other unimportant subjects were mentioned he returned to the East Timor problem ${ }^{17}$.

In other words, General Yusuf was saying clearly that a major humanitarian catastrophe was occurring in East Timor. He said that the assistance of international voluntary agencies including the ICRC would be very welcome. But there was no follow-up, and the death toll mounted.

Mr. D. Campbell and Mr. P. Alexander of the Australian Embassy visited West Timor from 10-14 August 1978 in the context of an Indonesian aid proposal. The Embassy traveled to Atambua, not far from the East Timorese border. Thus, it "presented an opportunity to gain some information on the general East Timorese situation as well as that existing on the West Timorese side of the border"18. They reported that the situation in East Timor was:

16 NAA: A1838, 3006-4-3 Part 24: Indonesia: Relations with Portuguese Timor.

17 NAA: A1838, 3006-4-3 Part 24: Indonesia: Relations with Portuguese Timor.

18 NAA: A1838, 3006-4-3 Part 24: Indonesia: Relations with Portuguese Timor. far more severe.....[They were shown] some very recent photographs... of the condition of the refugees in Bobonaro. The photographs depicted many sick, starving and malnourished women and children, typical of famine scenes throughout the world....The condition of the refugees, many of whom had in any case arrived in a desperate condition, was extremely poor. The Indonesian authorities were "doing almost nothing" to alleviate the situation. [They heard estimates that] at least $1.5 \%$ of the refugees were dying monthly and that in some groups the death rate was around $8 \%$ per month. Asked why the Indonesian authorities were not reacting to the gravity of the situation, [they were told that] it was largely because of the sensitivity of the local military commanders to publicity about the critical situation in many parts of East Timor. [Their informant] did not believe authorities in Dili were informing the central Government about the gravity of the problem which had emerged partially as a result of the Amnesty. For this reason he had written recently to General Benny Murdani in Jakarta, informing him of the need for urgent Government assistance. However, all he had received for his trouble was a rap over the knuckles from Dili military authorities who had flown to Atambua by helicopter to deliver the reprimand ${ }^{19}$.

The Australian officials concluded that "the Indonesian Government is not coming to grips with the critical condition of many refugees not far from the border with West Timor. Whether this is because of sensitivity to publicity or logistical problems is unclear, but the problem will probably become worse as more weak Fretilin followers come out of the hills to take up the Presidential amnesty. While, with the aid of international agencies, the Government appears to have managed the refugee situation on the western side of the border capably, in East Timor itself the situation has grown worse over the past twelve months. Unless there is firm Government action, people will continue to die of hunger..."20. Here was another warning of mass deaths-and here, yet again, was inaction as the death toll mounted.

\section{Knowledge of the Famine-Other Ambassadors}

The Australian ambassador visited East Timor along with nine other foreign ambassadors from 6 to 8 September 1978. The ambassadors were briefed that approximately 125,000 people had come down from the mountains, and that as many as a quarter of them

\footnotetext{
19 NAA: A1838, 3006-4-3 Part 24: Indonesia: Relations with Portuguese Timor.

20 NAA: A1838, 3006-4-3 Part 24: Indonesia: Relations with Portuguese Timor.
} 
were suffering from cholera, malaria, tuberculosis and advanced malnutrition. The Ambassador reported in confidence that the visit had been carefully controlled by the Indonesian authorities, who were clearly anxious that the tragic plight of many of the refugees seen should not be blamed on their administration. The US Ambassador Ed Masters agreed, writing that "these refugees were being given clothing and food in a show obviously set up for our benefit" although this may have been the usual procedure, he added. He said they were "in a pitiful state. The children had bloated stomachs and...many adults suffered from malaria, malnutrition and dysentery. There were also some cases of TB [tuberculosis]" (Masters, 1978). Many ambassadors came away shocked by the condition of the refugees. One visitor wrote an eyewitness account. The following is an excerpt:

Every week, scores of starving people, dressed in rags that cover only some parts of their bony bodies, drag children with sunken eyes, bloated stomachs and ugly leg sores down the tortuous mountain paths to make their way to Indonesian rehabilitation centres. Indonesians were handing out new clothes to replace their rags. Formed into two rows of welcoming humanity they waved redand-white Indonesian flags and shouted "selamat Datang" to ambassadors visiting them. I could clearly distinguished the newer arrivals from the older inhabitants, by their bony legs covered in sores. Malnutrition differed only in degree. The women swayed weakly, their hands gasping the flags moving slightly as they mumbled their messages of welcome. At a Red Cross station a Timorese woman slept on a stretcher on the floor dressed in rags with a piece of white cloth protecting her face from scores of flies attacking it. A medical aide from Jakarta would occasionally go into the room to fan away files from her eyes. The heat was unbearable. She had just come down from the hills two days earlier, and was suffering from cholera, he told me. The head of the district told journalists that 56 refugees had died on the march from the hills because of illness and malnutrition (no one used the word "starvation"). The visiting ambassadors were conspicuously moved by the sight. A few shook their heads in disbelief. The ambassador of Papua New Guinea, Dominic Diya told me: "We are a poor country but I have not seen anything like this. I am shocked to see the conditions of the refugees" (Chiang, 1978).

The Australian Broadcasting Corporation's correspondent in Jakarta, Warwick Beutler, reported on the Ambassadors' visit on Australian national public radio:

"Some of the Ambassadors were lost for words to describe the tragedy of thousands of people emerg- ing from the mountains of East Timor in appalling health. Papua New Guinea's Ambassador said he'd never seen human beings in such a bad state. Australia's Ambassador, Mr Tom Critchley, said their condition was deplorable....Canada's Ambassador, $\mathrm{Mr}$ Glen Shortliffe, describes it as a major humanitarian problem" (ABC, 1978).

He said that most envoys agreed that "only an international relief effort could prevent more people from dying." The Australian Embassy in Jakarta sent a cable back to Foreign Affairs headquarters in Canberra with suggestions on how to deal with questions in Parliament about this unwelcome publicity. "The people of Timor," it said, "have always been poor and most of them seem to have always lived barely above the subsistence line. Infrastructure is practically non-existent and the long-term problem is one of development. The land is poor, literacy rates are low and there are very few skilled workers. The Indonesian Government is therefore understandably anxious to ensure that any reference to the poor condition of the Timorese should make it clear that the problem is not repeat not of Indonesia's making. In short that East Timor was a poverty stricken country before the civil war started. Although the basic problem was not repeat not created by the recent civil war, the war exacerbated the position"21.

It will be recalled that the so-called civil war was fomented by Indonesia, lasted only three weeks in August 1975, and resulted in total deaths on all sides of fewer than 3,000 people. But the Australian Embassy was more interested in providing public relations cover for the Indonesian authorities. It chose to blame poverty and the civil war but did not mention the Indonesian military's use of napalm or its destruction of agricultural areas and other food sources such as livestock. The Australian Ambassador to Indonesia, Tom Critchley, explained why Indonesia was unwilling to allow international humanitarian assistance to enter East Timor:

While we obviously should not repeat not say so publicly, I believe that the Indonesians may be reluctant to seek foreign aid in large quantities in East Timor in particular, they are unlikely to want foreigners there administering it. If the Timorese are to become loyal Indonesians, the Indonesian Government must get the credit for relief and development work. The Indonesians may also want to avoid any impression that the assistance coming from abroad is greater than that coming from Jakarta. For this reason, I expect them to remain cautious about accepting foreign assistance ${ }^{22}$.

21 NAA: A1838, 3038-10-11-2 Part 5. Visits of Australians to Portuguese Timor.

22 NAA: A1838, 3038-10-11-2 Part 5. Visits of Australians to 
As the deaths due to the famine continued, the Indonesian military sealed East Timor off from the outside world. It continued to deny access to the ICRC, insisting that any foreign aid be channeled through the Indonesian Red Cross, over whose operations it exercised strong control.

The international relief effort was still more than one year away, and the East Timorese population, hungry, weakened and ill, continued to die. Meanwhile, on 3 October 1978 the Australian High Commission in Ottawa, Canada, received a copy of the report of the visit to East Timor by the Canadian Ambassador to Indonesia. Australian officials described it as "the most comprehensive account we have. The paras on the displaced persons (22-30) are quite graphic and para 33, which compares Indonesia's receptivity to various aid donors, including Australian worth reading"23. Nevertheless, the Ambassador's report (Paras 34-35) "develop[ed] an argument in favour of the Indonesian position at the UN". Canadian diplomats advised their Australian interlocutors that Australia's intended vote on the 1978 General Assembly resolution "would have more influence on the Canadian position that the actual content of the resolution"24. Australia did not support the 1978 Resolution, and the famine continued.

\section{Two Contrasting Civil Society Actions}

As the famine hit hard in 1978, some East Timor campaigners perpetrated a hoax that severely reduced their credibility; they falsified an advertisement for the OV-10 Bronco aircraft placed in the Far Eastern Economic Review by Rockwell International, the aircraft's manufacturer. The original advertisement featured a picture of the Bronco in action and a large caption: "the Bronco workhorse: Ask Thailand about it." They replaced "Thailand" with "Timor" and provided it to The Age, a major newspaper in Australia, in order to publicize US complicity in the Indonesian invasion. While the US was certainly complicit, the hoax was uncovered quickly and the activists' ploy served only to undermine their credibility. Rockwell International's Melbourne office checked with their corporate headquarters at the behest of the US Embassy in Australia, and was informed that the advertisement was a deception. The US Embassy issued a statement to the Australian media: "We find the purported advertisement to be a reprehensible effort to discredit an American corporation by the transparent use of a photomontage in order to misrepresent what they said in one of their advertisements" (Alston, 1978).

Portuguese Timor.

${ }^{23}$ NAA: A1838, 3038-10-11-2 Part 5. Visits of Australians to Portuguese Timor.

24 NAA: A1838, 3038-10-11-2 Part 5. Visits of Australians to Portuguese Timor.
The Age ran an embarrassed apologia that scorned Fretilin's credibility. It said that the "elaborate hoax" was sent in a letter to a sympathiser in Sydney signed by Fretilin's representative at the UN, Jose RamosHorta. The sympathiser, Mr Denis Freney, was "convinced the signature was genuine. Not only that-some of the matters raised in the letter indicate that only $\mathrm{Mr}$ Horta could have written it, he says." Meanwhile, it reported, Mr Ramos-Horta was unreachable-"said to be visiting Cuba with a Fretilin delegation" and "after Cuba he would be touring the Caribbean" (Lahey, 1978, p. 2).

At the same time, however, other campaigners were able to establish a high degree of credibility by conducting very sharp, accurate analysis of the situation in East Timor. The best example of this type of credibility-enhancing research in 1978 was conducted by Arnold Kohen, a US-based volunteer journalist in his twenties who spearheaded an energetic and highly effective campaign of raising public awareness with the help of a very small group of scholars. Kohen, who had formed the Cornell-Ithaca East Timor Defence Committee, was the lead writer of an analysis of the causes of the famine. The analysis discussed the food shortages, the Indonesian offensives and the level of US complicity. They sent it in the form of an emergency alert to groups and individuals in the USA and overseas. Kohen provided Professor Noam Chomsky, the renowned linguist and political activist, with a 40 page memo and 100 pages of documentation for a chapter in a book, The Political Economy of Human Rights. The book, co-authored with Edward Herman, gave prominence to East Timor, which became a signature issue of Chomsky (Chomsky \& Herman, 1979). Chomsky's profile brought the East Timor question into universities around the world, informing many people about the atrocities and their misrepresentation by governments and the media.

The 1978 analysis was disseminated after Congressional hearings had been held the previous year on the situation in East Timor. The hearings were significant because they placed on the record denials by the early Carter administration that the situation in East Timor continued to be serious. The arguments in the 1978 appeal and further analyses and questions developed from this quarter were highlighted at a December 1979 Congressional hearing. When the famine became an international political issue with starving people coming down from the mountains and mass deaths occurring in the camps, US officials had a lot of explaining to do because they had made it look as though the struggle in East Timor had ended.

\section{Explaining the Catastrophe}

In March 1979, the Indonesian military assessed that it had achieved its war aims; it had defeated FRETILIN in battle and eliminated most of its senior leaders. The remnants of the resistance were reduced to a few 
bands of ill-equipped guerrillas who were confined to the mountains, far away from the majority of the population in the towns and villages. Accordingly, on 26 March 1979, the Indonesian government declared that East Timor had been pacified. It established Subregional Military Command 164 (Korem 164), which was subordinated to the Regional Military Command (Kodam), headquartered in Bali. The significance of this reorganisation was that it was intended to show that East Timor had the same military administrative structure as Indonesia's other 26 provinces.

In April 1979 the Indonesian government permitted the ICRC to enter East Timor for the first time in almost four years to make a brief and preliminary on-the-spot survey. According to an internal United States State Department document, "It was not until the spring of 1979 that the Government of Indonesia felt East Timor to be secure enough to permit foreign visitors." Only after receiving the green light from the Indonesian military did the US Embassy move to initiate US Government disaster assistance. According to the same internal State Department document, "On June 1, 1979, the US Ambassador to Indonesia, Edward Masters, determined that a disaster of such a magnitude as to warrant US Government assistance existed in East Timor" (USAID, 1979, p. 1).

In November 1979, Australia's Department of Foreign Affairs acknowledged that there was "increased publicity in Australia" and "media criticism of the Indonesian Government for allowing such a situation to develop". As such, there was "strong public pressure on the Government to increase its aid contribution." It prepared a Cabinet submission noting the existence of "a substantial humanitarian problem in East Timor. As many as 200,000 Timorese are in urgent need of food and medical care." It noted that the ICRC "has faced major difficulties both to and within Timor" and that "within Timor, transport costs (\$3.3 million) represented a little under one half of the total cost" because "places in greatest need are only accessible by air." While the "provision of RAAF [Royal Australian Air Force] helicopters is feasible without detriment to current commitments" and "could have popular appeal within Australia", they "would be likely to cause presentational difficulties for the Indonesians." For that reason it opposed the provision of RAAF helicopters but suggested an offer of two million dollars to the Indonesian Government instead ${ }^{25}$.

With the prospect of an international relief effort-and foreign witnesses-the Indonesian government developed a narrative to explain the dire situation. It blamed the famine on the subsistence farming practices of the East Timorese and on drought.

For their part, Australian diplomats prepared "press

25 NAA: A1838, 3038-10-15 Part 11. Portuguese TimorAustralian Aid. guidance" so that the Foreign Minister could deal with media inquiries about the disaster. The Minister's comments, they wrote, should focus on "the positive question of what can usefully be done to help Timorese in need and steer them away from sterile analyses of past errors, body counts and who is to blame for what" $^{26}$. Drawing on Ambassador Critchley's September 1978 cable, ${ }^{27}$ they blamed the death toll on the civil war: "Many died during and because of the civil war before Indonesian intervention. Some thousands have left East Timor. We do not wish to get into discussions of how many died; what matters is helping the living." Protecting the Indonesian government from international criticism, they said it had "spent a large amount of money and effort on developing East Timor. Part of the economic problem is that Indonesia has inherited three centuries of colonial neglect.... They have had to react to a quickly changing situation and are doing their best"28.

Where were these starving people coming from? The US State Department's explanations resembled those advanced by the Indonesian regime. On 4 December 1979, State Department officials and US ambassador to Indonesia Edward Masters testified to the US Congress about the famine. The officials showed an aversion to the words "famine" and "starvation," referring instead to "acute malnutrition." For his part, Masters blamed the dire condition of the East Timorese people on "slash and burn agriculture," "extreme backwardness," "prevailing poverty," "lack of infrastructure," "erosion," and "drought." He mentioned the effects of the war briefly but chose to blame the Portuguese, who, as a contemporaneous analysis pointed out, "pulled out of their half of the island four years ago-and never carpet-bombed or defoliated the place" (Kohen \& Quance, 1980).

However, Kohen's razor-sharp 1978 analysis had already laid the groundwork for establishing the fact of a humanitarian catastrophe, and had squarely identified the Indonesian offensives as the causative factor. It had also highlighted the level of US complicity. Building on the structure of legitimacy created as a result of this credibility, Kohen worked intensively for several years with journalists and congressional officers, and played a crucial role in developing long-term Congressional contacts. Much of the pressure exerted on Indonesia in 1999, when East Timor was finally liberated, arose as a result of the structure of legitimacy that was built through painstaking efforts in these very important constituencies in 1979, the 1980s and the first two years of the 1990s, when the Santa Cruz massacre cat-

26 NAA: A1838, 3038-10-15 Part 12. Portuguese TimorAustralian Aid.

27 NAA: A1838, 3038-10-11-2 Part 5. Visits of Australians to Portuguese Timor.

28 NAA: A1838, 3038-10-15 Part 12. Portuguese TimorAustralian Aid. 
apulted East Timor to international prominence (Fernandes, 2011, pp. 63-86).

\section{Preventing Mass Atrocities in East Timor}

This paper has shown that early warning of mass atrocities in East Timor was available; that key states did not look away but were well-informed of the unfolding calamity caused by the Indonesian military's operations; that they provided military and diplomatic assistance to Indonesia; and that high-quality research by civil society activists did make a difference-not to ending the famine but to creating a structure of legitimacy as a result of this credible research and advocacy. The paper thus contributes to scholarship on mass atrocity prevention by showing that-at least in this case-there was no "early warning" problem but rather a failure to generate the political will to act on these warnings. Until that failure is addressed and early warnings are operationalised into an international commitment to act, efforts to end mass atrocities will be challenged by accusations of illegality, selectivity and cynicism.

\section{Acknowledgments}

I dedicate this paper to the late Dr. Andrew McNaughtan, an outstanding activist for East Timor.

\section{Conflict of Interests}

The author declares no conflict of interests.

\section{References}

Australian Broadcasting Corporation. (1978). AM Program, ABC Radio, 11 September 1978.

Alston, P. (1978). Timor-A hoax exposed. US Embassy Cable to US State Department, 26 July 1978. Released 20 March 2014.

CAVR. (2006). Final report of the commission for reception, truth and reconciliation. Dili, East Timor: CAVR.

Chiang, S. (1978, September 11). Land of suffering, hunger and disease. Straits Times.

Chomsky, N. \& Herman, E. (1979). The Washington con- nection and third world fascism (the political economy of human rights: volume I). Cambridge: South End Press.

Fernandes, C. (2011). The independence of East Timor. Eastbourne: Sussex Academic Press.

Hurst, J. (1978, January 12-18). God hasn't forsaken Timor. Nation Review.

Kohen, A. S. \& Quance, R.A. (1980, February 18). The politics of starvation. Inquiry.

Lahey, J. (1978, July 27). Timor bombshell off target. The Age.

Leadbeater, M. (2006). Negligent neighbour: New Zealand's complicity in the invasion and occupation of Timor-Leste. Nelson: Craig Potton Publishing.

Manning, B. (2003). Charlie india echo tango calling East Timor. In H. Alexander \& P. Griffiths (Eds.), A Few rough reds: Stories of rank and file organising. Canberra: Australian Society for the Study of Labour History.

Masters, E. (1978). Ambassador's visit to East Timor: GOI policy and possible US response. US Embassy Cable to US State Department, 14 September 1978. Released 20 March 2014.

McArthur, G. (1977, December 5). Indonesia anxious to replace decrepit arms. International Herald Tribune.

Moynihan, D. (1978). A dangerous place. New York: Berkley Books.

Nevins, J. (2005). A not-so-distant horror: Mass violence in East Timor. Ithaca: Cornell University Press.

Power, S. (2002). A problem from hell: America and the age of genocide. New York: Basic Books.

Staveteig, S. (2006). "Missing" persons in East Timor during the Indonesian occupation, 1975-1999. Paper presented at the Annual Meeting of the Population Association of America, Los Angeles.

Staveteig, S. (2007). How many persons in East Timor went "missing" during the Indonesian occupation? Results from indirect estimates. Laxenburg, Austria: International Institute for Applied Systems Analysis.

Taylor, J. (1991). Indonesia's forgotten war. London: Zed Books.

US Congress. (1977, July 19). House of Representatives, Human Rights in East Timor.

USAID. (1979, October 19). Situation report no 1. USA: Office of US Foreign Disaster Assistance.

\section{About the Author}

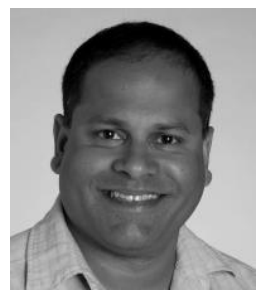

\section{Dr. Clinton Fernandes}

Clinton Fernandes is an Australian academic and former Australian Army officer. He teaches at the Australian Defence Force Academy campus of the University of New South Wales. Prior to becoming an academic, he spent 15 years in the Australian Army and served as the Australian Intelligence Corps - Principal Analyst (East Timor) in the final years of East Timor's independence struggle. In 2008 and 2009 he assisted the Australian Federal Police's War Crimes team on the subject of the Indonesian military and the East Timorese resistance. 